\title{
STRUCTURAL SETTING AND TECTONIC CONTROL OF KIMBERLITE AND ASSOCIATED ROCKS OF BRAZIL.
}

\author{
Almeida, ${ }^{(1)}$ F.F.M. de and Svisero, ${ }^{(2)}$ D.P.
}

(1) Instituto de Pesquisas Tecnológicas do Estado de São Paulo, Caixa Postal 7141, CEP 01000, S. Paulo, SP, Brazil; (2)Instituto de Geociências, Universidade de São Paulo, Caixa Postal 20899, CEP 01498, S. Paulo, SP, Brazil.

Although diamonds have been known in the Brazilian Platform since 1725 , kimberlites were discovered only in the late $1960^{\prime} \mathrm{s}$. Presently, kimberlites occur in at least eleven different provinces: Alto Paranaiba (Coromandel) and Bambuí (Ninas Gerais), Amorinópolis (Goiás), Paranatinga, FontanillasJuína and Pontes e Lacerda (Niato Grosso), Pimenta Bueno (Rondônia), Gilbués and Picos (Piaui), Lages (Santa Catarina) and Jaguari-Rosário do Sul (Rio Grande do Sul) (Svisero and Chieregati 1990).

The kimberlites of Alto Paranaíba are associated in space and possibly in time with carbonatites, basic-ultrabasic dykes trending NW-SE and several types of alkalic ultrabasic rocks, including lavas with lamproitic and kamafugitic affinities. Kimberlites and alkalic ultrabasic lavas occur mainly as diatremes intruding the Proterozoic Araxá and Brasilia Fold Belts developed along the western margin of the são Francisco Craton. Geological field work has revealed that the intrusions comprise several distinct fields centered around Catalão, Coromandel, Presidente Olegário, Carmo do Paranaíba and Araxá as well. The tectonic pattern of the area resembles that of northwestern Australia where diamond-bearing lamproites and kimberlites intrude fold belts around the Kimberley Craton (Jaques, Lewis and Smith 1986). Therefore, we predict that new findings of lamproites will certainly be registered in the future. In addition, there is a distinct possibility that the detrital diamonds of western Minas Gerais, which have been mined for two centuries, may be related to lamproites rather than to kimberlitic sources. Noreover, the presence of mineral indicators such as chromium pyrope garnet, magnesium ilmenite and chromiumspinel, among the heavies in the diamond-bearing conglomerates that presently cover large areas of Araxá and Bambui Groups, points to local sources for the diamonds.

The Bambui Province is located in southwest Ninas Gerais and comprise intrusions scattered over the southwest border of the São Francisco Craton, which was stabilized around $2.0 \mathrm{Ga}$. At this stage, we admit that the huge fracture zones reflected by the lineaments of Alto Paranaiba controlled the emplacement of kimberlites and associated rocks in both Alto Paranaíba and Bambui Provinces. Amorinópolis on the northern rim of Paraná Basin includes in adaition to kimberlites several types of alkalic ultrabasic rocks intrusive into the Proterozoic 
Araguaia Fold Belt. The Provinces of Paranatinga and Fontanillas-Juina are located in the Rio Negro-Juruena Mobile Belts made up of rocks of continental crust formed between 1.55 and $1.75 \mathrm{Ga}$. Pimenta Bueno lies on the border of the Rio NegroJuruena and Rondoniense Nobile Belts, the latter having developed arouna $1.3 \mathrm{Ga}$. Pontes e Lacerda in remote southwest Nato Grosso is also intrusive in rocks of the Rondoniense Belt. Apparently, there is a remarkable regional trend joining the Provinces of Alto Paranaíba, Arnorinópolis, Paranatinga, Fontanillas-Juina and Pimenta Bueno. This possible megalineament trends $\mathrm{N} 35 \mathrm{~W}$ and may have played an important role in kimberlite emplacement either via hot spots or through reactivation during the late Cretaceous (Almeida 1986).

Kimberlites of Gilbués (southern Brazil) and Picos (eastern Piauí) are intrusive in Paleozoic ana $\mathbb{N}_{1}$ esozoic sediments of the Parnaiba Basin. Intrusions in Picos were controlled by the magnetic lineament of Senador Pompeu or Serra Grance and those of Gilbués by the regional Transbrasiliano lineament. These NE-SW structures converge in middle Brazil before disappearing beneath the sediments of the Paraná Basin in line with the lamproites and basanites of Asunción, Paraguay. Lages in central eastern Santa Catarina and JaguariRosário do Sul in central southern Rio Grande do sul are poorly known. The Lages diatremes are intrusive in Paleozoic sediments of the Paraná Basin and are associated with breccias, carbonatites, melilitites and other alkaline rocks. In spite of the lack of information on the basement in Lages it is thought to consist of rocks of the Proterozoic Itajai Fold Belt. Kimberlites of Jaguari-Rosário do Sul are intrusive into basalt flows of the Paraná Basin, whose basement is supposea to be the Craton Rio de la Plata.

In sumary, the majority of the kimberlites and associated rocks known in Brazil up to this moment are intrusive in fold belts or mobile belts of Proterozoic age. Notable exceptions include the Bambui Province on the border of São Francisco Craton and Jaguari-Rosário do Sul probably on Rio de la Plata Craton. Nothing is known about Amazon Craton mainly due to the tropical covering forest. Finally, we mention the occurrences of detrital diamonds in metaconglomerates of $\mathrm{N}_{1}$ iddle Proterozoic Espinaço and Roraima Belts whose sources are completely unknown.

\section{REFERENCES}

Almeida, F.F.N. de (1986) Regional distribution and tectonic relations of the post-paleozoic magmatism in Brazil. Revista Brasileira de Geociências, 16, 325-349 (in Portuguese). 
Jaques, A.L., Lewis, J.D. and Smith, C.B. (1986) The kimberlites and lamproites of Western Australia. Geological Survey od Western Australia, Bulletin 132, 268p.

Svisero, D.P. and Chieregati, L.A. (1990) Geologic context of diamond and kimberlites in Brazil. Special Publication, Instituto de Geociências da Universidade de São Paulo, p. 132138 (in Portuguese).

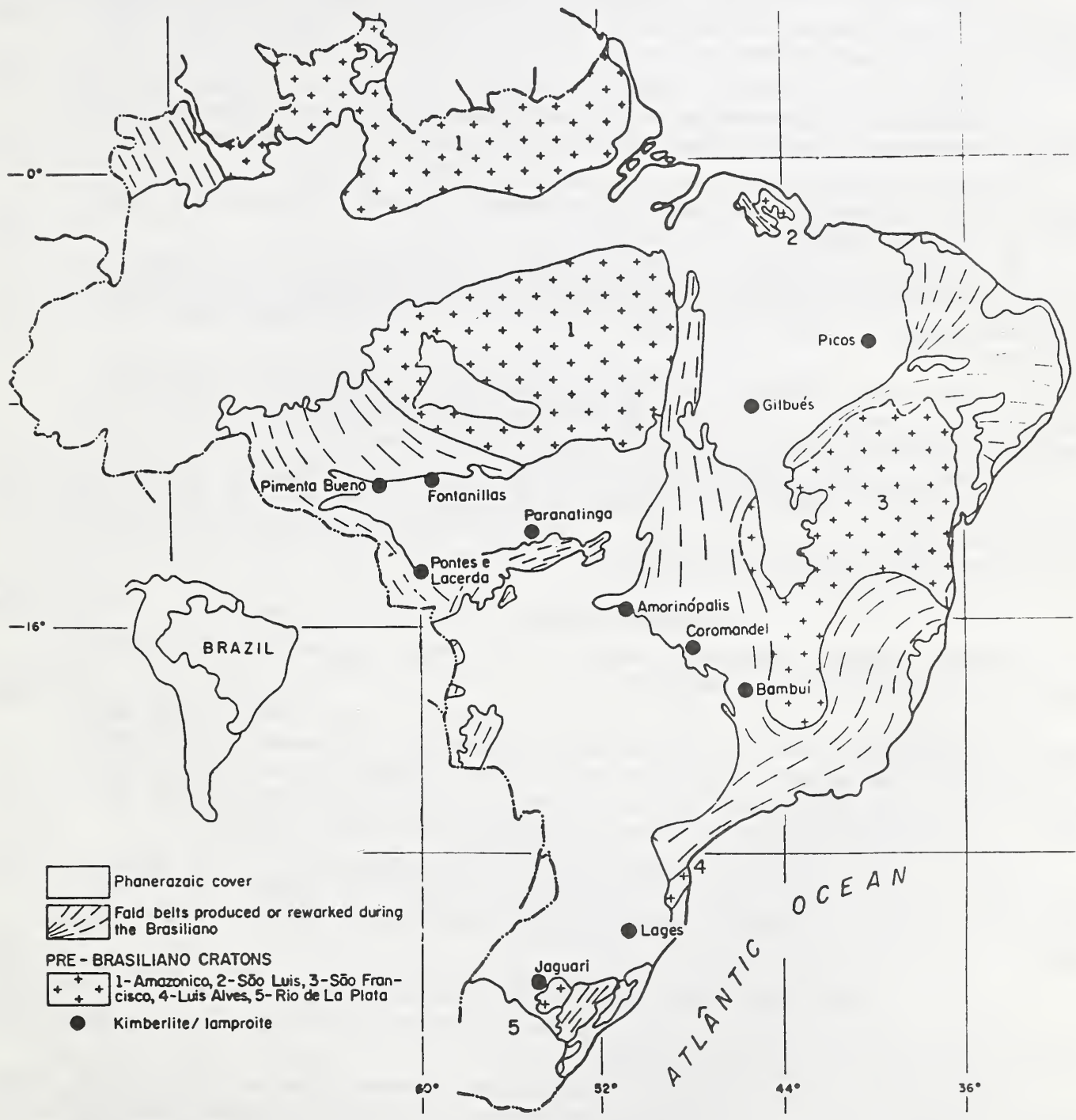

FIg.1-SIMPLIFIED TECTONIC FRAMEWORK OF BRAZIL AND SITES OF KIMBERLITE/ LAMPROITE OCCURRENCES 